\title{
MORALITAS PEMIMPIN DALAM CARIYOS RAJA SIYEM
}

\author{
Dwinda Ayu Kusumawardhini ${ }^{1}$ dan Darmoko ${ }^{2}$ \\ Program Studi Jawa \\ Fakultas Ilmu Pengetahuan Budaya Universitas Indonesia \\ E-mail: dwindaayuk@gmail.com ${ }^{1}$,pak.darmoko@gmail.com²
}

\begin{abstract}
Abstrak
Dunia kesusasteraan mengenal prosa sebagai salah satu genre sastra di samping genre-genre yang lain. Untuk mempertegas pengertian dan keberadaan genre prosa, sering dipertentangkan dengan genre lainhya. Karya sastra itu sendiri mencakup berbagai karya tulis dalam bentuk prosa, puisi, dan drama. Karya sastra prosa dalam bentuk naskah dapat dipandang sebagai benda konkrit yang dapat dilihat atau dipegang. Dalam pengertian ini naskah mencakup alat tulis, sampul, aksara, beserta sistem ejaannya, tinta, rubrikasi, iluminasi, hiasan-hiasan yang muncul pada lembar-lembar alat tulis. Naskah prosa yang telah dialihaksarakan menjadi sebuah suntingan teks dapat dijadikan bahan diskusi dari berbagai perspektif. Penelitian ini menggunakan bahan naskah Cariyos Raja Siyem yang telah dialihaksaranakn dari aksara Jawa ke aksara Latin. Penelitian ini menganalisis unsur-unsur yang turut membentuk keseluruhan karya sastra sehingga diperoleh makna nilai-nilai yang terkandung di dalamnya. Nilai-nilai tersebut terumuskan di dalam sebuah moralitas kepemimpinan yang dikemas berdasarkan latar belakang budaya Jawa. Hasil kajian menunjukkan bahwa teks Cariyos Raja Siyem mengandung nilai-nilai moralitas keutamaan dan ekspresi simbolik, yaitu bijaksana dalam sikap dan tindakan, pandai berpidato dan berdiplomasi, rendah hati, ekspresi simbolik kepemimpinan Jawa, dan busana ekspresi simbolik keagungan raja.
\end{abstract}

Kata kunci: sastra, struktur, moral, pemimpin, Jawa.

\section{LEADER MORALITY IN CARIYOS RAJA SIYEM}

\author{
Dwinda Ayu Kusumawardhini' dan Darmoko ${ }^{2}$ \\ Javanese Study Program \\ Faculty of Humanities Universitas Indonesia \\ E-mail:dwindaayuk@gmail.com ${ }^{1}$,pak.darmoko@gmail.com ${ }^{2}$
}

\begin{abstract}
The world of literature recognizes prose as one of the literary genres in addition to other genres. To reinforce the understanding and existence of the prose genre, it is often contested with other genres. The literary work itself includes various works in the form of prose, poetry and drama. Prose literary works in the form of manuscripts can be seen as concrete objects that can be seen or held. In this sense the manuscript includes stationery, covers, letters, along with the spelling system, ink, rubrication, illumination, decorations that appear on the sheets of stationery. Prose texts that have been translated into text edits can be used as discussion material from various perspectives. This study uses Cariyos Raja Siyem manuscript material that has been translated from Javanese script to Latin script. This study analyzes the elements that form the entire literary work in order to obtain the meaning of the values contained therein. These values are formulated in a leadership morality that is packaged based on Javanese cultural background. The results of the study show that the Cariyos Raja Siyem text contains the values of virtue morality and symbolic expression, namely wise in attitude and actions, clever speech and diplomacy, humility, symbolic expression of Javanese leadership, and the symbolic expression of the majesty of the king.
\end{abstract}

Keywords: literature, structure, morals, leaders, Javanese. 


\section{PENDAHULUAN}

Menurut Koentjaraningrat (1979: 186-187) terdapat 3 wujud kebudayaan, yaitu kebudayaan sebagai ide, gagasan, nilai, atau norma; kedua kebudayaan sebagai aktivitas atau pola tindakan dalam masyarakat; dan ketiga wujud kebudayaan sebagai bendabenda hasil karya manusia. Kebudayaan merupakan satu kesatuan yang tidak terpisah satu dengan yang lain, baik pikiran, ide-ide gagasan, maupun tindakan manusia yang menghasilkan benda-benda budaya tersebut salah satunya adalah berupa karya sastra. Karya sastra adalah karya seni berupa bahasa yang digambarkan atau diimplementasikan menggunakan kata-kata. Terdapat sejumlah bentuk karya sastra, seperti naskah dan teks, novel, prosa, puisi, macapat, dan lain sebagainya.

Dunia kesusasteraan mengenal prosa sebagai salah satu genre sastra di samping genre-genre yang lain. Untuk mempertegas pengertian dan keberadaan genre prosa, sering dipertentangkan dengan genre yang lain, misalnya dengan puisi, pertentangan itu sendiri hanya bersifat teoritis (Nurgiyantoro, 2015:1). Istilah prosa sebenarnya dapat mengandung pengertian yang lebih luas, meliputi berbagai karya tulis, bukan dalam bentuk puisi atau drama, tiap baris dimulai dari margin kiri penuh sampai margin kanan. Prosa dalam pengertian ini tidak hanya terbatas pada tulisan yang digolongkan sebagai karya sastra, melainkan juga berbagai karya nonfiksi termasuk penulisan berita dalam surat kabar (Nurgiyantoro, 2015:1-2). Menurut Barried dalam buku Pengantar Ilmu Filologi Jawa, naskah adalah benda konkrit yang dapat dilihat atau dipegang. Naskah mengandung mantra lama, baik lama dalam jarak waktu maupun lama dalam jarak budaya yang tercermin melalui unsur tradisional pada alas tulis, proses produksi dan reproduksi, dan unsur-unsur lainnya (Karsono,2013:5). Dalam pengertian ini, naskah mencakup alat tulis, sampul, aksara, beserta sistem ejaannya, tinta, rubrikasi, iluminasi, hiasan-hiasan yang muncul pada lembar-lembar alat tulis. Baik alas tulis, aksara, tinta, rubrikasi, iluminasi, maupun hiasan merupakan bagian dari naskah karena keberadaannya seperti halnya wujud naskah dapat disentuh, diraba, dipegang, atau dirasakan secara langsung oleh indera. Hal ini tentu berbeda dengan teks atau wacana yang merupakan kandungan naskah. Terdapat beberapa bentuk teks, seperti geguritan, macapat, dan prosa atau yang lebih dikenal dengan naratif.

Penelitian ini menggunakan bahan teks Cariyos Raja Siyem. Naskah Cariyos Raja Siyem itu sendiri ditulis pada 2 april 1871 dan diteliti pada tahun 2016 oleh 
seorang Mahasiswi Sastra Daerah Untuk Sastra Jawa FIBUI angkatan 2012. Naskah Cariyos Raja Siyem terdapat di Perpustakaan Nasional Republik Indonesia dengan nomer koleksi KBG 281. Naskah Cariyos Raja Siyem merupakan naskah yang berbentuk prosa dan memiliki 31 halaman. Naskah tersebut ditulis menggunakan aksara Jawa dan menggunakan bahasa Jawa. Peneliti memilih teks Cariyos Raja Siyem (dari suntingan teks) sebagai sumber data, karena teks tersebut ditulis pada tahun 1871 yang pada dasarnya memiliki ciri dan corak budaya yang berbeda dengan ekspresi budaya masa kini.

Di dalam teks Cariyos Raja Siyem menarasikan seorang raja asing yang berkunjung ke tanah Betawi (Indonesia) dan penduduk Betawi pada masa itu memberikan penilaian terhadap raja melalui sudut pandang budaya Jawa. Penelitian ini menggunakan teori Burhan Nurgiyantoro yang terdapat dalam bukunya berjudul Teori Pengkajian Fiksi. Buku Teori Pengkajian Fiksi merupakan buku yang diterbitkan oleh Gadjah Mada University Press, cetakan pertama tahun 1995. Teks Cariyos Raja Siyem tersebut mengisahkan tentang seorang raja dari Bangkok, Thailand bernama Raja Siyem yang sedang mengunjungi Tanah Batavia. Teks ini menjelaskan perjalanan seorang raja ketika sampai di Tanah Batavia dan aktivitas yang dilakukan ketika di Tanah Batavia, hingga kembali ke negri asalnya di Bangkok, Thailand. Di dalam naskah ini juga dijelaskan bagaimana antusiasme petinggi-petinggi, tentara, hingga masyarakat tanah Batavia untuk menyambut kedatangan Raja Siyem.

Teks Cariyos Raja Siyem baru diteliti oleh hanya ditemukan satu penelitian. Penelitian tersebut dilakukan dengan sistem kerja filologi, yaitu untuk menyunting teks dari aksara jawa kemudian diubah menjadi aksara latin, dan juga terjemahan beberapa inti cerita saja. Penelitian sebelumnya tidak membahas secara konsep struktural sastra. Dalam penelitian ini akan dilakukan secara berbeda. Jika pada penelitian sebelumnya menggunakan metode filologi, pada penelitian ini akan menggunakan pendekataran struktural sastra.

\section{METODE PENELITIAN}

Sumber data penelitian ini menggunakan teks naskah Cariyos Raja Siyem yang merupakan teks hasil suntingan dari Ayuna Langit Aprisyani Pamungkas, mahasiswa Program Studi Sastyra Daerah Untuk sastra Jawa FIBUI. Naskah Cariyos Raja Siyem 
itu sendiri ditulis pada tahun 1871, suatu masa penulisan yang dilatarbelakangi oleh kolonial belanda bercokol di tanah air Indonesia, khususnya di tanah Batavia. Naskah Cariyos Raja Siyem disimpan di Perpustakaan Nasional Republik Indonesia, yang bertempat di Jl. Merdeka Selatan, Gambir, Jakarta Pusat. Dengan nomer koleksi KBG 281. Naskah Cariyos Raja Siyem merupakan naskah berbentuk prosa yang memiliki 30 halaman.

Adapun yang dimaksud metode penelitian meliputi pendekatan, cara kerja, konsep, dan kerangka teori. Penelitian ini menggunkan pendekatan objektif, yaitu suatu pendeketan yang menitik beratkan pada karya sastra itu sendiri. Namun demikian bukan berarti penelitian ini tidak berupaya keluar dari teks untuk menghubungkannya hal-hal di dalam teks dengan di luar teks namun juga mencari relasi timbal balik antara sebuah penggambaran dengan yang digambarkan (konteks). Konsep kepemimpinan yang diacu untuk mendeskripsikan citra Raja Siyem digunakan pemikiran Suwardi Endraswara dalam Falsafah Kepemimpinan Jawa. Teori Burhan Nurgiyantoro dalam bukunya yang berjudul Teori Pengkajian Fiksi digunakan untuk menganalisis unsur-unsur di dalam karya sastra yang turut membangun secara keseluruhan teks. Unsur-unsur di dalam karya sastra tersebut terdiri dari plot, tema, penokohan, dan latar. (Nurgiyantoro, 2005:14). Penelitian ini menggunakan metode kualitatif. Menurut Creswell (2010: 4), penelitian kualitatif merupakan metode-metode umtuk mengeksplorasi dan memahami makna yang oleh sejumlah individu atau sekelompok orang dianggap berasal dari masalah sosial atau kemanusiaan. Penelitian kualitatif sangat tergantung terhadap informasi dari objek /partisipan pada: ruang lingkup yang luas, pertanyaan yang bersifat umum, pengumpulan data yang sebagian besar terdiri atas kata-kata/teks dari partisispan, menjelaskan dan melakukan analisa terhadap kata-kata dan melakukan penelitian secara subyektif (Creswell, 2010: 46). Salah satu tujuan umum dalam penelitian kualitatif yaitu mencakup informasi tentang fenomena utama yang dieksplorasi dalam penelitian (Creswell, 2010: 167).

\section{HASIL DAN PEMBAHASAN}

\section{Deskripsi Nilai-Nilai dalam Teks Cariyos Raja Siyem}

Penelitian mengimplementasikan konsep etika jawa dalam Falsafah Kepemimpinan Jawa yang menjelaskan bahwa setiap jenis kepemimpinan dan etnis 
memiliki ciri-ciri tersendiri. Setiap wilayah juga mengemban kepemimpinan yang berbeda-beda. Ciri-ciri tersebut akan merubah sesuai tuntutan zaman. Ciri kepemimpinan Jawa pun mengalami perubahan-perubahan dari waktu kewaktu. Ciri kepemimpinan Jawa lebih bermodus pada hal-hal yang bersifat tradisional. Bahkan modernitas pun oleh pemimpin Jawa diolah kembali dengan aneka tradisi (Endraswara,2013:7).

Kepemimpinan dalam budaya Jawa memiliki beberapa ciri seperti yang terkandung pada Asthabrata, Tri Darma Mangkunegara, dan yang terkandung dalam Serat Negarakertagama. Pada penelitian ini peneliti menggunakan Serat Negarakertagama untuk menjelaskan sifat seorang raja yang terkandung dalam Cariyos Raja Siyem dan untuk meneliti perspektif orang jawa kepada seorang Raja asing yang sedang berkunjung ke Betawi.

Dalam buku Falsafah Kepemimpinan Jawa dijelaskan jika dalam Serat Negarakertagarama, terdapat sifat Patih Gadjah Mada yang patut diteladani oleh pemimpin bangsa. Namun, dari 15 sifat tersebut ada yang masih relevan dengan kondisi kepemimpinan dan ada pula yang kurang relevan. Sifat kepemimpinan termaksud adalah: 1) Wignya, artinya kebijaksanaan dalam memerintah. Ia penuh hikmah dalam menghadapi berbagai kesukaran. Akhirnya bisa berhasil menciptakan ketentraman; 2) Mantriwira, pembela negara yang berani karena benar; 3) Wicaksaneng naya, bijaksana dalam sikap dan tindakan. Kebijaksanaannya selalu terpancar dalam setiap perhitungan dan tindakan, baik ketika menghadapi lawan maupun kawan, bangsawan maupun rakyat jelata; 4) Matanggwan, memperoleh kepercayaan karena tanggung jawab yang besar sekali dan sealu menjunjung tinggi kepercayaan yang dilimpahkan di atas batu kepalanya; 5) Satya bhakti aprabu, bersikap setia dengan hati yang tulus ikhlas kepada negara serta pemimpin di atasnya; 6) Wagmi wak, pandai berpidato dan berdiplomasi mempertahankan atau meyakinkan sesuatu; 7) Sarjjawopasama, berwatak rendah hati, berbudi pekerti, berhati emas, bermuka manis, dan penyabar; 8) Dhirotsaha, terusmenerus bekerja rajin dan sungguh-sungguh; 9) Tan lalana, selalu tampak gembira meskipun didalamnya sedang gundah gulana; 10) Diwyacitta, mau mendengarkan pendapat orang lain dan bermusyawarah; 11) Tan sastrisna, tidak memiliki pamrih pribadi untuk menikmati kesenangan yang berisi girang dan birahi; 12) Sihsamastabhuwana, menyayangi seluruh dunia sesuai dengan falsafah hidup bahwa segala 
yang ada didunia ini adalah fana, bersifat, bersifat sementara. Ia menghargai alam semesta sebagai rahmatan lil alamin; 13) Ginon pratidina, selalu mengerjakan yang baik dan membuang yang buruk; 14) Sumantri, menjadi abdi negara yang senonoh dan sempurna kelakuannya; 15) Anayaken musuh, bertindak memusnahkan muuh, ia tak gentar menewaskan musuh, meskipun sebenarnya selalu menjalin kasih sayang kepada sesama negara (Endraswara, 2013:92-93).

Berdasarkan penjelasan diatas, terdapat sifat-sifat Kanjeng Raja Siyem yang diterapkan oleh Kanjeng Raja Siyem. Sifat-sifat tersebut sesuai dengan yang disebutkan dalam Serat Negarakertagama. Sifat tersebut adalah Wicaksaneng naya, Wagmi wak, dan Sarjjawopasama.

1.1 Wicaksaneng naya adalah bijaksana dalam sikap dan tindakan. Kebijaksanaannya selalu terpancar dalam setiap perhitungan dan tindakan, baik ketika menghadapi lawan maupun kawan, bangsawan maupun rakyat jelata (Endraswara, 2013:92). Kanjeng Raja Siyem memiliki sifat wicaksaneng naya. Sifat tersebut digambarkan dengan cerita yang disampaikan oleh penulis, dan ditunjukan ketika Kanjeng Raja Siyem baru tiba di Betawi dan menyapa masyarakat Betawi. Sifat tersebut dibuktikan dengan kutipan berikut.

"Raja sarawuhipun ngebum, lajeng kapethukaken kanjeng tuwan litnan jendral jogtedhak saking baita urmat mariyem mungel rambah kaping 21." (CRS, 1871:9) Samanten sareng Kanjeng Raja Siyem tumedhak saking baita dipunkanthi kanjeng tuwan litnan jendral dereng ngantos tindak kawan tindak tebihipun saking baita kula tumunten lajeng rumiyin saking niyat kula badhe ningali wonten gapuranipun kanjeng tuwan besar, pirsa atedhakipun Raja Siyem saking rata.” (CRS, 1871:10).

Terjemahan:

"Setibanya Kanjeng Raja Siyem dipelabuhan, kemudian bertemu dengan Kanjeng Tuan Letnan Jendral kemudian dibunyikan mariam sebanyak 21 kali.

Ketika bersama dengan Kanjeng Raja Siyem turun dari kapal kemudian kanjeng tuan letnan jndral belum sampai didekat kapal yang saya lihatkemudian dari sana saya melihat di gapura kanjeng tuan besar menunggu kedatangan Raja Siyem".

1.2 Wagmi wak adalah pandai berpidato dan berdiplomasi mempertahankan atau meyakinkan sesuatu. Kanjeng Raja Siyem memiliki sifat wagmi wak. Sifat tersebut digambarkan oleh penulis melalui tindakan yang dilakukan oleh Kanjeng Raja Siyem. Sifat tersebut ditunjukan melalui kutipan berikut. 
"Sesampunipun para tuwan ingkang ageng-ageng ngaturi tabe dhateng Kanjeng Raja Siyem gentos Kanjeng Raja Siyem matur dhateng kanjeng Tuwan besar angaturaken para punggawa Siyem. Pangeran kalih majeng ngaturaken tabe dhateng kanjeng tuwan besar, kanjeng tuwan besar jumeneng saking palenggahan maringi tabe dhateng pangeran kalih lajeng gentos dhateng para punggawa sadaya sesampunipun ngaturi tabe, kanjeng tuwan besar para punggawa Siyem lenggah kursi ngajeng kanan kiri para tuwan sami kondur.”(CRS, 1871:12-13)

\section{Terjemahan:}

"Setelah para pejabat memberikan pidatonya, kemudian giliran Kanjeng Raja Siyem memberikan pidatonya utuk kanjeng tuan besar memperkenalkan rombongan Siyem. Kemudian pangeran Siyem memberikan pidatonya kepada kanjeng tuan besar, kemudian kanjeng tuan besar memberikan pidatonya untuk Kanjeng Raja Siyem beserta rombongan. Setelah memberikan pidatonya kanjeng tuan besar dan rombongan Siyem duduk bersama."

1.3 Sarjjawopasama adalah berwatak rendah hati, berbudi pekerti baik, berhati emas, bermuka manis dan penyabar. Kanjeng Raja Siyem memiliki sifat sarjjawopasama yang digambarkan oleh penulis melalui tindakan yang dilakukan oleh kanjeng Raja Siyem. Hal tersebut dibuktikan dengan adanya kutipan berikut.

"Kanjeng Raja Siyem rawuh para sinyo menyanyi sakelangkung rame ngantos kados gerah kasapta wau Kanjeng Raja mirsani para sinyo menyanyi katingal sakelangkung saku ing dalem penggalih.” (CRS, 1871:15)

\section{Terjemahan:}

"Kanjeng Raja Siyem tiba dan para siswa bernyanyi dengan begitu antusiasnya ketika dilihat oleh Kanjeng Raja. Kanjeng Raja melihat penampilan para siswa dan membuat senang hati Kanjeng Raja Siyem."

"Kanjeng Raja Siyem ingkang sukanipun ing penggalih aningal sinyo ing sekolahan raja, lajeng maringi yatra sedasa ewu rupiyah. Dhateng tuwan ingkang nguwasani ing sekolahan raja dhawuhipun Kanjeng Raja Siyem, yatra sedasa ewu rupiyah wau kalebetan dhateng kantor bang bingahipun saben taun kadamel gancar. Dhateng para sinyo ingkang katarima anggenipun sekolah utawi ingkang ketingal nemen anggenipun marsudi dhateng kasagetan." (CRS, 1871:16).

\section{Terjemahan:}

"Kanjeng Raja Siyem yang sedang berbahagia karena melihat penampilan para siswa-siswa, kemudian memberikan uang sebesar sepuluh ribu rupiah. Diberikan bepada tuan yang mengelola sekolah tersebut, kemudian uang sebesar sepuluh ribu rupiah kemudian dibawa kebang untuk ditabung untuk keperluan sekolah." 


\section{Ekspresi Simbolik Kepemimpinan Jawa}

Dalam buku Falsafah Kepemimpinan Jawa, konsep kepemimpinana yang paling populer adalah astha brata. Konsep astha brata termuat dalam berbagai karya sastra, antara lain Serat Ramayana, Serat Ramajarwa, Serat Nitisruti, Serat Tumurunin Wahyu Maya, dan Serat Makutharama (Endraswara, 2013:103). Astha brata adalah delapan "laku" yang harus ditempuh seseorang bila sedang menjalankan tampuk kepemimpinana. Delapan laku tersebut sebagai personifikasi delapan unsur alamiah yang dijadikan panutan watak (watak wantun) seorang pemimpin. Kedelapan unsur tersebut meliputi delapan karakter unsur-unsur alam yakni: bumi, langit, angin, samudra-air, rembulan, matahari, api dan bintang (Endraswara, 2013:105).

Menurut Endraswara dalam buku Falsafah Kepemimpinan Jawa, Astha brata berarti delapan perilaku yang dimiliki seorang pemimpin delapan perilaku tersebut adalah sebagai berikut (Endraswara, 2013:103-104).

2.1 Laku hambeging candra: artinya, bertindak seperti sinar purnama. Maksudnya seorang pemimpin harus memberikan penerangan yang menyejukan seperti bulan bersinar terang benderang tetapi tidak panas.

2.2 Laku hambeging dahana: artinya, seorang pemimpin harus tegas seperti api yang sedang membakar. Namun, pertimbangannya berdasarkan akal sehat yang dipertanggung jawabkan, sehingga tidak membawa kerusakan di muka bumi.

2.3 Laku hambeging kartika: artinya, seorang pemimpin harus tetap percaya diri meskipun dalam dirinya ada kekurangan. Ibarat bintang-bintang diangkasa, walaupun ia sangat kecil tapi dengan optomis memancarkan cahyanya, sebagai sumbangan terhadap kehidupan.

2.4 Laku hambeging kisma: artinya, seorang pemimpin yang selalu berbelas kasih dengan siapa saja. Kisma memiliki arti tanah. Tanah tidak memperdulikan siapa yang menginjaknya, semua dikasihani.

2.5 Laku hambeging samirana: artinya, seorang pemimpin harus beriwa teliti dimana saja berada. Baik buruk rakyat harus diketahui oleh mata kepala sendiri, tanpa menggantungkan laporan daru bawahan saja.

2.6 Laku hambeging samodra: artinya, seorang pemimpin harus mempunyai sifat pemaaf sebagaimana samudra raya yang siap menampung apa saja yang hanyut dari daratan. 
2.7 Laku hambeging surya: artinya, seorang pemimpin harus memberi inspirasi pada bawahannya ibarat matahari yang selalu menyinari bumi dan memberi energi pada setiap makhluk.

2.8 Laku hambeging tirta: artinya, seorang pemimpin harus adil seperti air yang selalu rata permukannya.

Delapan perilaku tersebut merupakan sifat-sifat seorang raja.

Berdasarakan penjelasan diatas, Kanjeng Raja Siyem memiliki sifat yang terkandung dalam Astha Brata. Kanjeng Raja Siyem memiliki sifat laku hambeging surya. artinya, seorang pemimpin harus memberi inspirasi pada bawahannya ibarat matahari yang selalu menyinari bumi dan memberi energi pada setiap makhluk. Sifat Kanjeng Raja Siyem yang termasuk sifat laku hambeging surya digambarkan oleh penulis melalui kutipan berikut.

"Ingkang punika sadaya tiyang ing salebetipun nagari Betawi, ageng alit jalu estri sadaya bangsa, sami muji sayektosipun ing kabar wau, saha memuji mangkatena punika. Pramila sadaya bangsa ageng alit sami pangajeng-ngajengipun, sabab ciptanipun ing manah kalih prakawis." (CRS, 1871:1)

Terjemahan:

"Seluruh rakyat Betawi, anak-anak, orang dewasa, laki-laki dan perempuan semua senang mendengar berita tersebut. Dan memuja kabar tersebut. Oleh sebab itu, seluruh masyarakat Betawi berharap karena telah membuat bahagia hari masyarakat Betawi kala itu."

Berdasarkan uraian dan pembuktian diatas maka dapat dirumuskan bahwa Kanjeng Raja Siyem memiliki salah satu sifat yang terkandung dalam Astha Brata, yaitu sifat Laku hambeging surya.

\section{Busana Ekspresi Simbol Keagungan Raja}

Menurut Soemarsaid Moertono dalam bukunya Negara dan Usaha Bina Negara di Jawa Masa Lampau, dijelaskan jika seorang raja dimuliakan melalui pakaian yang ia gunakan. Menurut Moertono nilai kemuliaan tersebut disebut dengan kotang Antasukma (baju Antasukma). Kegunaan tersebut termasuk dalam sarana kegunaan untuk memuliakan raja. Dengan Kotang Antasukma menyanjung tinggi raja melalui pusaka. Arti pentingnya terletak dalam kekuatan gaib yang dianggap terkandung didalam pusaka tersebut (Moertono, 1985:77). Pusaka meliputi berbagai macam barang dengan asal 
mula yang menurut tradisi juga berbeda-beda. Barang-barang tersebut bisa berupa pakaian, mahkota, keris, pedang atau tombak.

Dalam naskah Cariyos Raja Siyem nilai kemuliaan/keagungan seorang raja digambarkan oleh penulis melalui pakaian yang dikenakan oleh Kanjeng Raja Siyem ketika tiba di Betawi. Pakaian tersebut dijelaskan melalui kutipan berikut.

"Kanjeng Raja Siyem wau taksi taruna saha pekik watawis saweg yuswa kali dasa warsa, ngagem busana raja cara Siyem sarta adi luhung ingkang nunggil sarata kanjeng tuwan litnan jendral kalih kanjeng tuwan jendral laut tiga kanjeng tuwan sekretaris jendral.... Sawingkingipun rata kencana rata gerbong pelag ing ngriku wonten Pangeran Siyem taksih lare watawis saweg umur 9 utawi 10 taun, sami busana endah anamung busananipun Kanjeng Raja Siyem utawi pangeran kalih wau sami cara Siyem wujudipun busana ngagem kaos dumugi nginggil jengku, lajeng ngagem sapatu ngagem nyamping sutra. Kacawisaken dados bilih dipuntingali saking katebihan kados ngangge lancingan panji-panji, namung rasukanipun ugi kados jas cekak kabludir mawi topi cara Inggris tanda dhestar. (CRS, 1871:10)

\section{Terjemahan:}

"Kanjeng Raja Siyem yang ternyata seorang taruna dan masih berusia sekitar 20 tahun, menggunakan pakaian raja dengan cara Siyem dan adi luhung yang juga bersatu yaitu kanjeng tuan letnan jendra, kanjeng tuan jendral laut, dan kanjeng tuan sektretaris jendral..... Di depan gerbang kereta kencana ada Pangeran Siyem yang masih kecil berusia 9 atau 10 tahun, ia menggunakan pakaian yang juga indah dan memiliki cara berpakaian yang sama dengan Kanjeng Raja Siyem. Wujud dari pakaian tersebut adalah kaos hingga diatas lutut, kemudian menggunakan sepatu dan mengunakan sutra. Terlihat juga dari kejauhan jika menggunakan celana pendek berpangakat, tetapi pakaian tersebut juga seperti jas dan juga menggunakan topi seperti orang Inggris."

Berdasarkan penjelasan diatas, Kanjeng Raja Siyem juga dapat terlihat jika ia merupakan sosok yang diagungkan melalui pakaian yang ia gunakan.

Menurut Nurgiyantoro, terdapat unsur-unsur pembangun pada novel dan cerpen seperti, plot, tema, penokohan, dan latar secara umum dapat dikatakan lebih rinci (Nurgiyantoro, 2005:14).

Burhan Nurgiyantoro (2005:14), mengatakan bahwa terdapat unsur-unsur pembangun dalam novel. Unsur-unsur pembangun tersebut dalam sebuah novel berupa plot, tema, penokohan, dan latar secara umum dapat dikatakan lebih rinci dan kompleks daripada unsur-unsur cerpen. Dalam menganalisis naskah Cariyos Raja Siyem, peneliti terlebih dahulu akan menganalisis mengenai struktur cerita yang terkandung dalam 
naskah CRS. Istilah tokoh menunjuk pada orangnya, pelaku cerita. Watak, perwatakan, dan karakter menunjuk pada sifat dan sikap para tokoh seperti yang ditafsirkan oleh seorang pembaca, lebih menunjukan pada kualitas pribadi seorang tokoh. Penokohan dan karakteristik sering juga disamakan artinya dengan karakter dan perwatakan menunjukan pada penempatan tokoh-tokoh tertentu dengan watak tertentu dalam sebuah cerita (Nurgiyantoro, 2005:247).

Pada Naskah CRS, tokoh dibagi menjadi dua yaitu tokoh utama dan tokoh tambahan. Kula Sebagai Tokoh Utama. Pada naskah CRS, Kula berperan sebagai narator yang juga berperan dalam sebagai rakyat Batawi. Kula sebagai tokoh utama karena sebagai pencerita yang menceritakan kisah Kanjeng Raja Siyem selama mengunjungi Batawi. Kanjeng Raja Siyem Sebagai Tokoh Utama. Pada naskah CRS, Kanjeng Raja Siyem berperan sebagai tokoh utama. Karena pada naskah tersebut terlihat jika Kanjeng Raja Siyem mendominasi cerita pada naskah. Kanjeng Raja Siyem sering menjadi pembahasan dan muncul dalam setiap peristiwa. Pada naskah CRS penulis menggambarkan jika Kanjeng Raja Siyem merupakan seorang raja yang baik, ramah, murah hati, dan bijaksana ketika berkunjung dan bertemu dengan masyarakat Batawi.

Pangeran Siyem Sebagai Tokoh Tambahan. Pada naskah CRS diceritakan jika pangeran siyem adalah anak dari Raja Siyem. Pangeran siyem berperan sebagai tokoh tambahan yang juga menjadi daya tari masyarakat Batawi. Sedaya Bangsa Sebagai Tokoh Tambahan. Pada naskah CRS diceritakan jika sedaya bangsa sangat antusias untuk menyambut kedatangam Raja Siyem. Sedaya bangsa berperan sebagai tokoh tambahan pada CRS. Prajurit Militer, Prajurit Selam, Prajurit Usar, dan Prajurit Selam Sebagai Tokoh Tambahan. Pada naskah CRS terdapat prajurit-prajurit yang merupakan abdi negara untuk menjadi negara. Pada naskah CRS prajuri-prajurit tersebut ditugaskan untuk menyiapkan segala keperluan untuk menyambut kedatangan Raja Siyem. Komendhan Sebagai Tokoh Tambahan. Pada naskah CRS komendhan berperan sebagai tokoh tambahan. Dimana komendhan adalah seseorang yang memimpin dikantor pelabuhan. Para Sinyo Sebagai Tokoh Tambahan. Pada naskah CRS para sinyo berperan sebagai tokoh tambahan. Para sinyo adalah anak laki-laki berkebangsaan eropa dan merupakan peranakan belanda. Kanjeng Tuan Sekretaris Jendral, Kanjeng Tuan Jendral Laut, dan Kanjeng Tuan Risidhenil Sebagai Tokoh Tambahan. Kanjeng tuan 
sekretaris jendral, kanjeng tuan jendral laut, dan kanjeng tuan risidhenil berperan sebagai tokoh tambahan. Kanjeng tuan sekertaris jendral, kanjeng tuan jendral laut, dan kanjeng tuan risidhenil muncul ketika penyambutan kedatangan Kanjeng Raja Siyem.

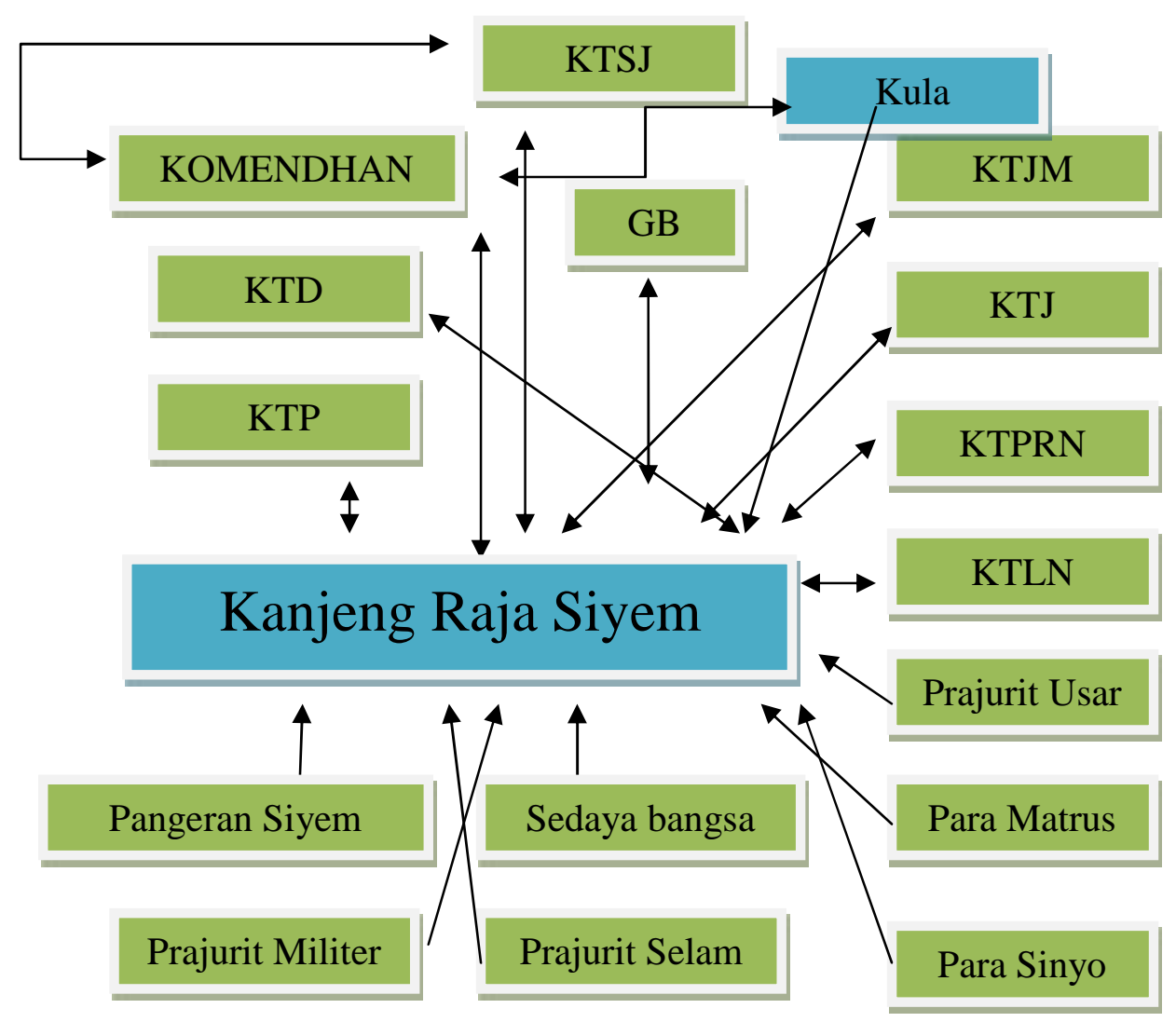

Gambar 1. Penjelasan Mengenai Hubungan Antar Tokoh

\section{Keterangan bagan:}

니 : Merupakan tokoh-tokoh yang mendukung tokoh utama

: Merupakan tokoh utama

$\longleftrightarrow \quad$ : Merupakan tanda adanya timbal balik antar tokoh tambahan dengan tokoh utama.

$\longrightarrow \quad$ : Merupakan tanda bahwa tidak ada timbal balik anatar tokoh tambahan dengan tokoh utama.

\section{Keterangan Singkatan :}

KTSJ : Kanjeng Tuan Sekretaris Jendral

KTJ : Kanjeng Tuan Jelaut

KTJM : Kanjeng Tuan Jendral Mayor 
KTPDN : Kanjeng Tuan Presiden Radpa Nindhi

KTD : Kanjeng Tuan Dhireksi

KTP : Kanjeng Tuan Prasinjen

GB : Gubernur Jendral

KTLN : Kanjeng Tuan Litnan Jendral

Plot merupakan unsur fiksi yang penting, bahkan tidak sedikit orang yang menanggapinya sebagai yang terpenting diantara berbagai unsur fiksi yang lain (Nurgiyantoro, 2005:164). Untuk menyebut plot, secara tradisional, orang juga sering menggunakan istilah alur atau jalan cerita, sedangkan dalam teori-teori yang berkembang lebih kemudian dikenal adanya istilah struktur naratif, susunan, dan juga sujet. Menurut stanton (1965:14) dalam buku Teori Pengkajian Fiksi mengemukakan bahwa plot adalah cerita yang berisi urutan kejadian, namun tiap kejadian itu hanya dihubungkan secara sebab-akibat, peristiwa yang satu disebabkan atau menyebabkan terjadinya peristiwa yang lain (Nurgiyantoro, 2005:167). Menurut Nurgiyantoro plot dibagi menjadi 3, yaitu peristiwa, konflik, dan klimaks. Menurut Nurgiyantoro terdapat beberapa bagian dalam plot yaitu peristiwa, konflik, dan klimaks (Nurgiyantoro, 2005:173).

Menurut Luxemberg dalam Nurgiyantoro menjelaskan jika peristiwa dapat diartikan sebagai peralihan dari suatu keadaan ke keadaan yang lain, peralihan dari satu aktivitas ke aktivitas yang lain (Nurgiyantoro, 2005:173). Peristiwa dibagi menjadi 3 yaitu peristiwa fungsional, peristiwa kaitan, dan peristiwa acuan. 1. Peristiwa Fungsional. Peristiwa fungsional merupakan peristiwa-peristiwa yang menentukan dan atau mempengaruhi perkembangan plot. Urutan-urutan peristiwa fungsional merupakan inti cerita sebuah cerita fiksi yang bersangkutan. Pada naskah CRJ terdapat beberapa peristiwa fungsional yang didalamnya merupakan peristiwa-peristiwa inti yang dilakukan Kanjeng Raja Siyem dan rombongan ketika berada di Batawi. 2. Peristiwa Kaitan. Peristiwa kaitan adalah peristiwa-peristiwa yang berfungsi mengaitkan peristiwa-peristiwa penting dalam pengurutan penyajian cerita atau secara plot. (Nurgiyantoro, 2005:174).

Pada CRS terdapat peristiwa-peristiwa kaitan yang berfungsi sebagai pengait antara peristiwa biasa dengan peristiwa penting. 3. Peristiwa Acuan. Peristiwa acuan 
adalah peristiwa yang tidak secara langsung berpengaruh dan atau berhubungan dengan pengembangan plot, melainkan mengacu pada unsur-unsur lain, misalnya berhubungan dengan masalah perwatakan atau suasana yang melingkupi batin seorang tokoh. Pada CRS terdapat juga peristiwa-peristiwa acuan yang secara tidak langsung berhubungan dengan pengambangan plot. pada awal cerita merupakan kejadian pengenalan yang berupa narasi dari pencerita yang mengenalkan mengenai teks naskah tersebut merupakan penceritaan. Pada awalan diceritakan jika gubernur jendral akan kedatangan tamu yang berasal dari negara asing yaitu Kanjeng Raja Siyem. Kanjeng Raja Siyem datang ke Betawi dalam rangka perjalanannya untuk mengungi negara-negara tetangga. Kanjeng Raja Siyem akan tiba di Betawi pada tanggal 25 Maret tahun 1871.

Kabar tersebut tersiar hingga ke masyarakat luas dan membuat senang hati masyarakat Betawi. Seluruh masyarakat Betawi, abdi negara, dan juga para petinggi Betawi sangat antusias untuk menerima kedangan Kanjeng Raja Siyem. Pada Peristiwa tengah dijelaskan atau diceritakan jika pada tanggal 25 Maret ternyata Kanjeng Raja Siyem belum tiba di Betawi. Kanjeng Raja Siyem baru tiba di Betawi pada tanggal 26 Maret dan disambut baik oleh seluruh masyarakat Betawi dan dibunyikannya meriam sebanyak 21 kali sebagai tanda jika Kanjeng Raja Siyem dan rombongan sudah tiba di Betawi. Pada hari-hari berikutnya Kanjeng Raja Siyem yang bijaksana kemudian melakukan perjalanan di Betawi selama beberapa hari. Beliau dan rombongan mengunjungi sekolah yang dibangun oleh belanda dan disambut oleh para siswa-siswi yang berkebangsaan eropa. Selanjutnya Kanjeng Raja Siyem Dan rombongan mengunjungi Kebun Binatang Jikini. Disana sudah banyak tuan-tuan dan juga nyonyanyonya yang sedang mengunjungi Kebun Binaatang Jikini. Setelah mengunjungi Kebun Bintang Jikini Kanjeng Raja Siyem dan rombongan juga mengunjungi museum untuk melihat koleksi-koleksi yang tersimpan di museum negara pada masa itu. Pada bagian akhor cerita dijelaskan jika perjalanan Kanjeng Raja Siyem selama di Betawi telah selesai Kanjeng Raja Siyem dan rombongan bersiap kembali untuk melanjutkan perjalanan ke Semarang dan meninggalkan jakarta. Kepergian Kanjeng Raja Siyem juga di antarkan oleh pejabat-pejabat tinggi negara Betawi. 
Tabel 1. Urutan Peristiwa

\begin{tabular}{|c|c|c|}
\hline No. & Rangkaian Peristiwa & Tahapan Alur \\
\hline 1. & $\begin{array}{l}\text { Tersiarnya berita jika gubernur jendral akan } \\
\text { kedatangan tamu yaitu Kanjeng Raja Siyem yang } \\
\text { merupakan raja dari negara asing. }\end{array}$ & Peristiwa fungsional \\
\hline 2. & $\begin{array}{l}\text { Karena tersebarnya kabar tersebut membuat } \\
\text { masyarakat negara Betawi sangat senang dan } \\
\text { bersuka cita, gubernur jendral menyiapkan segala } \\
\text { keperluan untuk menyambut datangnya Kanjeng } \\
\text { Raja Siyem. }\end{array}$ & Peristiwa kaitan \\
\hline 3. & $\begin{array}{l}\text { Tersiar kabar kembali jika Kanjeng Raja Siyem akan } \\
\text { tiba pada tanggal } 25 \text { Maret. }\end{array}$ & Peristiwa fungsional \\
\hline 4. & $\begin{array}{l}\text { Pada tanggal } 25 \text { Maret terdengar suara } \\
\text { dibunyikannya meriam sebagai tanda jika Kanjeng } \\
\text { Raja Siyem akan segera tiba. }\end{array}$ & Peristiwa acuan \\
\hline 5 . & $\begin{array}{l}\text { Kanjeng Raja Siyem ternyata akan tiba pada hari } \\
\text { minggu jam } 13 \text { siang. }\end{array}$ & Peristiwa kaitan \\
\hline 6. & $\begin{array}{l}\text { Pada hari minggu pencerita mencari tau dan bertanya } \\
\text { kepada komandan yang sedang berjaga mengenai } \\
\text { kedatangan Kanjeng Raja Siyem. }\end{array}$ & Peristiwa acuan \\
\hline 7. & $\begin{array}{l}\text { Menurut penglihatan pencerita, dijelaskan jika } \\
\text { bangsa Siyem memiliki rupa yang mirip dengan } \\
\text { bangsa Jawa pada masa itu. }\end{array}$ & Peristiwa acuan \\
\hline 8. & $\begin{array}{l}\text { Terdengar suara meriam sebanyak } 21 \text { kali yang } \\
\text { menandakan jika Kanjeng Raja Siyem sudah tiba. }\end{array}$ & Peristiwa fungsional \\
\hline 9. & $\begin{array}{l}\text { Dari kejauhan sudah terlihat kapan milik Kanjeng } \\
\text { Raja Siyem. }\end{array}$ & \\
\hline 10. & $\begin{array}{l}\text { Setibanya di Pelabuhan, kemudian Kanjeng Raja } \\
\text { Siyem disambut oleh Letnan Jendral yang sudah siap } \\
\text { untuk menerima kedatangan Kanjeng Raja Siyem. }\end{array}$ & Klimaks \\
\hline 11. & $\begin{array}{l}\text { Kanjeng Raja Siyem mengunjungi sekolah yang } \\
\text { didirkan oleh belanda. Ketika tiba Kanjeng Raja } \\
\text { Siyem disambut oleh siswa-siswi dari golongan } \\
\text { belanda yang bersekolah disana. }\end{array}$ & Peristiwa fungsional \\
\hline 12. & $\begin{array}{l}\text { Kanjeng Raja Siyem mengunjungi Kebun Binatang } \\
\text { Cikini bersama rombongannya. }\end{array}$ & Peristiwa fungsional \\
\hline 13. & $\begin{array}{l}\text { Kanjeng Raja Siyem datang berkunjung ke Museum } \\
\text { untuk melihat-lihat benda koleksi musem. }\end{array}$ & Peristiwa fungsional \\
\hline 14. & $\begin{array}{l}\text { Pulangnya Kanjeng Raja Siyem beserta rombongan } \\
\text { untuk melanjutkan perjalanan ke semarang dan } \\
\text { dimeriahkan kembali oleh masyarakat Batawi }\end{array}$ & Peristiwa fungsional \\
\hline
\end{tabular}




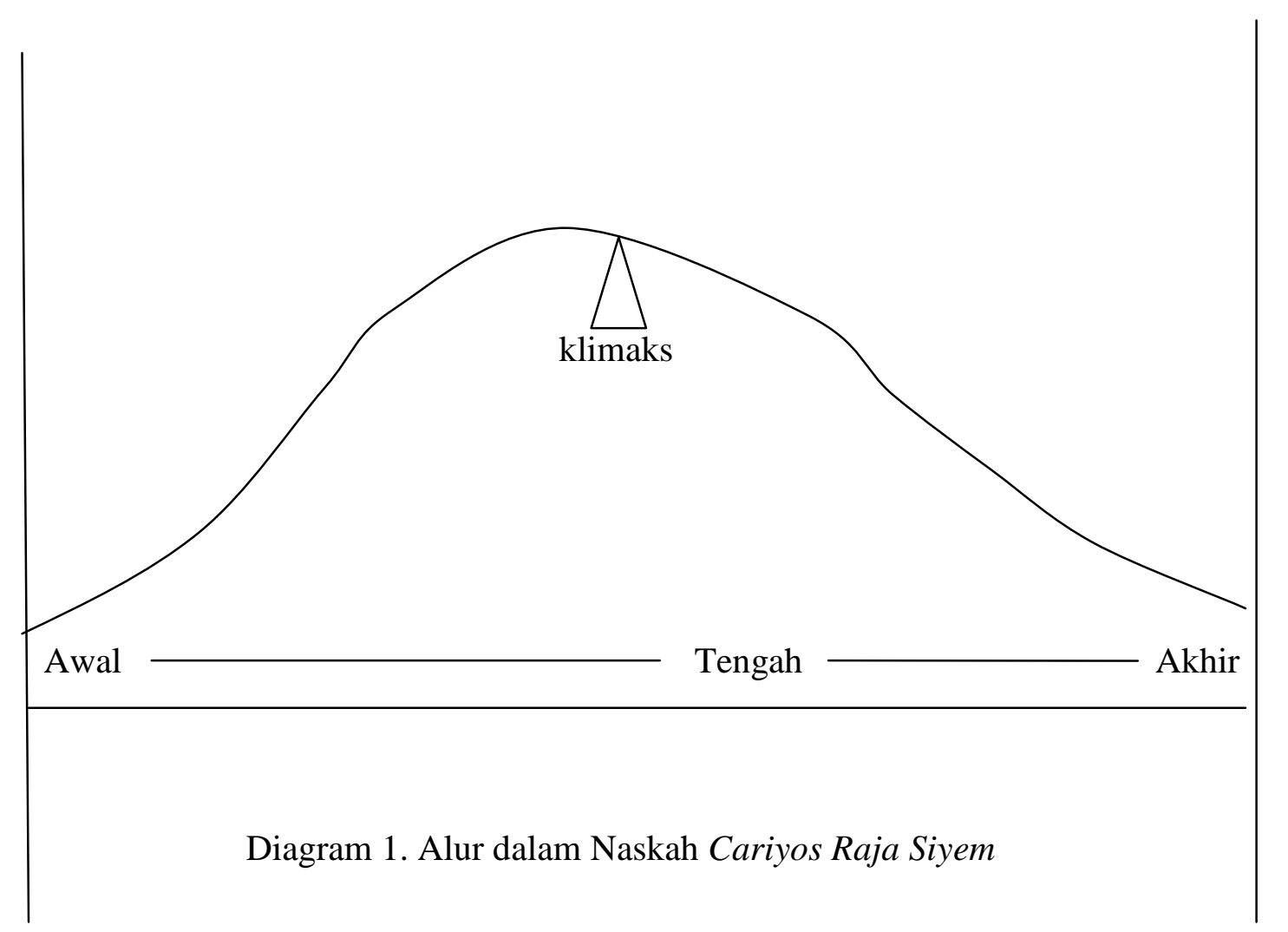

Keterangan Diagram :

$\triangle \quad$ : Letak klimaks

Awal : Peristiwa pada bagian awal cerita

Tengah : Peristiwa pada bagian tengah cerita

Akhir : Peristiwa pada akhir cerita

Tema adalah gagasan (makna) dasar umum yang menopang sebuah karya sebagai struktur semantis dan bersifat abstrak yang secara berulang-ulang dimunculkan lewat motif-motif dan biasanya dilakukan secara implisit (Nurgiyantoro, 2005:115). Berdasarkan analisis unsur-unsur diatas peneliti menyimpulkan jika pada CRS terdapat tema yang diangkat yaitu mengenai gambaran nilai-nilai keagungan seorang raja asing melalui persepktif Jawa. Tema tersebut diangkat melalui cerita mengenai Kanjeng Raja Siyem yang datang dari negara asing (thailand) untuk melakukan perjalan kenegaranegara tetangga dan Betawi merupakan salah satu tujuan Kanjeng Raja Siyem untuk dikunjungi. Nilai keagungan Kanjeng Raja Siyem digambarkan melalui upacara penyambutan yang dibuat oleh pejabat Betawi pada masa itu dan juga antusias masyarakat untuk menyambut kedatangan Kanjeng Raja Siyem. 
Secara umum moral menunjuk pada pengertian (ajaran tentang) baik buruk yang diterima umum mengenai perbuatan, sikap, kewajiban dan sebagainya; akhlak, budi pekerti, susila (Nurgiyantoro,2005:429). Pada naskah CRJ juga terdapat nilai-nilai moral yang baik yang dimunculkan secara tersirat. Baik dari golongan masyarakat, pejabat tinggi, hingga Raja Siyem sendiri.

\section{KESIMPULAN}

Moralitas Pemimpin adalah sebuah konsep tentang sifat yang seyogyanya dimiliki oleh seorang pemimpin atau Raja. Terdapat sejumlah sifat-sifat baik yang sebaiknya dimiliki oleh seorang raja yaitui bijaksana, murah hati, tidak serakah, mau berbagi atau dermawan, berani, dan yang lainnya sebagainya. Padangan kepemimpinan menurut Serat Negarakertagama dan Astha Brata menginspirasi pembahasan sifat kepemimpinan yang patut diteladani oleh pemimpin bangsa. Berdasarkan Serat Negarakertagama, Kanjeng Raja Siyem memiliki 3 sifat yang terkandung dalam Serat Negarakertagama. Sifat tersebut adalah 1) Wicaksaneng naya, yaitu bijaksana dalam bersikap dan bertindak. 2) Wagmi wak, yaitu pandai berpidato dan berdiplomasi. 3) Sarjjawopasama, yaitu berwatak rendah hati, berbukti pekerti baik, berhati emas, bermuka manis, dan penyabar.

Sifat Kanjeng Raja Siyem tergambarkan melalui konsep dalam Astha Brata, yang berisi delapan laku bagi seorang pemimpin. Dalam teks Cariyos Raja Siyem, tokoh Kanjeng Raja Siyem memiliki sifat yang sesuai dengan Astha Brata. Sifat tersebut adalah laku hambeging surya (berwatak matahari), artinya seorang raja/pemimpin mampu memberikan inspirasi kepada khalayak ramai dan juga harus memberikan contoh yang baik kepada orang-orang dibawah pimpinannya. Sifat laku hambeging surya yang dimiliki oleh Kanjeng Raja Siyem ditunjukan melalui tindakan serta gelar yang dimiliki oleh Kanjeng Raja Siyem.

Analisis unsur-unsur struktural pada CRS saling berhubungan satu dengan yang lainnya. Melalui analisis tokoh dan penokohan, plot, tema, latar, dan juga nilai moral secara keseluruhan bermuara pada keberadaan tokoh utama. Tokoh-tokoh bawahan lain seperti Kanjeng Tuan Besar, Gubernur Jendral, Kanjeng Tuan Sekretaris Jendral, Kanjeng Tuan Jelaut, Kanjeng Tuan Jendral Mayor, Sadaya Bangsa, Tiyang Cina, dan Para Sinyo sebagai penopang tokoh utama dan melegitimasi keberadaan tokoh utama. 
Terdapat empatbelas peristiwa yang terdiri dari peristiwa fungsional, peristiwa kaitan, peristiwa acuan dan juga klimaks. Alur pada teks CRS memiliki plot maju yang dibuktikan melalui pencatatan narasi dari peristiwa satu ke peristiwa lainnya. Peristiwaperistiwa yang dialami oleh tokoh tidak lepas dari latar yang mendukungnya. Latar tempat, latar waktu, dan latar sosial-budaya meliputi Betawi, Kota, Pelabuhan, Kantor Pelabuhan, Sekolah, Kebun Bintang Tjikini, dan Gedung Museum; penyebutan tanggal, bulan, hari, tahun hingga waktu seperti pagi, siang, dan sore; perlengkapanperlengkapan yang digunakan untuk penyambutan kedatangan Kanjeng Raja Siyem dan kegiatan-kegiatan yang dilakukan oleh masyarakat Betawi kala itu.

Teks Cariyos Raja Siyem mengandung gambaran tentang nilai-nilai keagungan seorang raja asing melalui persepktif Jawa bahwa penduduk Betawi pada masa itu berpandangan moralitas pemimpin. Kanjeng Raja Siyem sebagai raja asing yang memiliki sifat-sifat keagungan pemimpin Jawa.

\section{DAFTAR PUSTAKA}

Achmad, S. (2017). Filsafat Jawa. Yogyakarta: Araska.

Creswell, J. Research Design:Qualitative and Quantitative approaches. California:Sage Publication.

Koentjaraningrat. (1979). Ilmu Antropologi I. Jakarta: UI Press

Magnis-Suseno, F. (1984). Etika Jawa. Jakarta: Gramedia.

Moertono, S. (1985). Negara dan Usaha Bina-Negara di Jawa Masa Lampau : Studi Tentang Masa Mataram II, Abad XVI Sampai XIX. Jakarta: Yayasan Obor Indonesia.

Nurgiyantoro, B. (2005). Teori Pengkajian Fiksi. Yogyakarta: Gadjah Mada University Press.

Saputro, Karsono H. (2008). Pengantar Filologi Jawa, Jakarta: Wedatama Widya Sastra

Suwardi Endraswara, M. (2013). Falsafah Kepemimpinan Jawa. Yogyakarta: NARASI.

Teeuw, A. (1984). Sastra dan ilmu sastra : Pengantar Teori Sastra. Jakarta: PT Dunia Pustaka Jawa. 